\title{
sciendo
}

CIVIL AND ENVIRONMENTAL ENGINEERING REPORTS

E-ISSN 2450-8594

CEER 2019; 29 (1): 066-091

DOI: $10.2478 /$ ceer-2019-0006

Original Research Article

\section{IMPACT OF DEVELOPMENT OF INFRASTRUCTURE FOR CHARGING ELECTRIC VEHICLES ON POWER DEMAND IN THE NATIONAL POWER SYSTEM}

\author{
Łukasz SZABŁOWSKI ${ }^{1}$, Paweł BRALEWSKI ${ }^{2}$ \\ Warsaw University of Technology, Warsaw, Poland
}

\begin{abstract}
The following paper focuses on the electric vehicles sector development and its possible influence on power system load in Poland. The goal is to estimate the increase of power demand resulting from the electric cars charging. First of all, the current legal environment, which provides a framework for the e-mobility sector evolution, was described. Furthermore, the technical process of electric vehicles charging was depicted and the applicable methods of cooperation between e-mobility and power system were proposed. The quantitative analysis of the impact of the electric vehicles charging on the power demand in the National Power System was conducted. The input data and adopted assumption were specified. The structure of the calculation model and the differences between analyzed scenarios were described. The outcome obtained for the National Power System and Warsaw distribution area were presented.

Keywords: e-mobility, electric vehicles, electric vehicles charging, National Power System
\end{abstract}

\section{INTRODUCTION}

The issue of the transport sector in the European Union member states, concerns mainly its negative impact on the environment and the high degree of dependence

\footnotetext{
1 Corresponding author: Warsaw University of Technology, Institute of Heat Engineering, Nowowiejska st 21/25,00-665 Warsaw, Poland, e-mail: lukasz.szablowski@itc.pw.edu.pl.
} 
on crude oil, which is obtained mainly through its import from third countries. For these reasons, more and more attention is paid to efforts to change the current shape of the industry, which manifests itself, among others, in documents published by the European institutions. The chosen direction is to increase the share of alternative fuels in transport by expanding the infrastructure of refueling and charging vehicles based on unconventional fuels, promotion of unconventional technologies and common technology standards.

In elaboration [1] issued by the European Commission on 3 March 2010, the objective was set to increase the competitiveness and energy security that is to be achieved through more efficient use of energy resources. A year later, the White Paper on Transport was adopted [2], which noted the need to reduce energy dependence. As one of the means to meet this challenge, the development of alternative fuels is mentioned. It is also proposed to reduce greenhouse gas emissions in the transport sector by $60 \%$ by 2050 , taking the 1990 levels as the baseline.

The first binding purpose addressed to European Union Member States was developed within the framework of Directive 2009/28/EC [3], which determined the required share of renewable fuels in the transport fuel market in the amount of $10 \%$ in 2020 . This led to the popularization of the so-called biofuels, whose implementation in European conditions was relatively simple and cheap compared to other renewable energy sources for transport. As a result of industry consultations, a communication [4] was also elaborated, which indicates electricity, hydrogen, biofuels, natural gas and liquid as fuels with the greatest potential to replace petroleum in transport.

The latest document on the development of alternative fuels for transport Directive 2014/94/EU [5], to a greater extent than previous acts, deals with the topic of electric vehicles, indicating new recommendations and targets for electromobility. Member States were obliged, among others, to present the National Policy Framework within the scope of the areas addressed by the Directive until November 16, 2016. Within their framework, they are required to present, among others:

- assessing the current state and future development of the market in relation to alternative fuels in the transport sector and assessing the development of alternative fuels infrastructure,

- national general and specific objectives for the development of alternative fuels infrastructure,

- the measures necessary to meet national general and specific objectives,

- measures that can support the development of alternative fuels infrastructure in public transport services, 
- urban and suburban agglomerations, other densely populated areas and networks to be equipped with publicly accessible recharging points for electric vehicles.

In the light of the above obligations imposed under Directive 2014/94/EU, the Polish Ministry of Energy presented on September 20, 2016. The Clean Transport Package [6], which includes:

- National framework for alternative fuels infrastructure development policy [7],

- Electromobility Development Plan [8],

- Low-emission Transport Fund.

The national framework for the development policy of alternative fuels infrastructure meets the requirements of the Directive on the development of alternative fuels infrastructure. The assessment of current state of charging infrastructure for electric vehicles (as well as those supplied with other alternative fuels) was conducted and proposition of a number of changes regarding tax instruments and technical regulations was issued. From the point of view of this work, however, the most important analysis will be the introduction of the main national target, which includes the existence of:

- 50,000 electric vehicles by 2020 ,

- 6,000 charging points with normal power and 400 high-power charging points in 2020 ,

- $\quad 1,000,000$ electric vehicles in 2025 .

The legal framework for the development of electromobility was established in the draft Act on electromobility and alternative fuels [9] published by the Minister of Energy on 27 April 2017.

Electric cars can also be powered with fuel cells. The technology of fuel cells is intensively developed at the Warsaw University of Technology [10-13].

It is likely that a large number of electric cars can increase the differences between the peaks and valleys of demand for electricity, which is why it is worth considering the methods of energy storage [14-17].

\section{METHODS AND MATERIALS}

The cooperation of electric cars with the power system should be understood not only in the form of energy consumption from electric networks, but also in Vehicle-To-Grid applications, where the power is delivered form the vehicle's battery to the power grid. The number of currently used charging modes and the differences in the parameters of individual batteries are the main problem in modeling the charging process. 
The simplest diagram of the electrical circuit including the battery and charger is shown in Fig. 1. From the power supply side, the electric charger is supplied with a current of $i_{c}$ and a voltage $V_{c}$. The output parameters from the charger are the current and voltage $V_{\text {pack. }}$. The current with such parameters supplies the battery with an internal resistance $R_{e q}$. The voltage of the battery being charged has been marked in the diagram as $\mathrm{V}_{\text {oceq }}$.

The basic parameter of the battery which is subject to modeling is the level of SOC (State of Charge), which can be expressed by the formula:

$$
S O C=\frac{Q}{Q_{\text {nom }}}
$$

$Q \quad$ actual battery capacity,

$Q_{\text {nom }}$ nominal battery capacity.

However, the change in the charge level SOC can be determined from the following formula:

$$
\triangle S O C=S O C(t)-S O C\left(t_{0}\right)=\frac{1}{Q_{\text {nom }}} \int_{t_{0}}^{t} i(t) d t
$$

The DOD (Depth Of Discharge) parameter, which value reflects the size of the battery discharge, is also used to describe the battery condition:

$$
D O D=1-S O C
$$

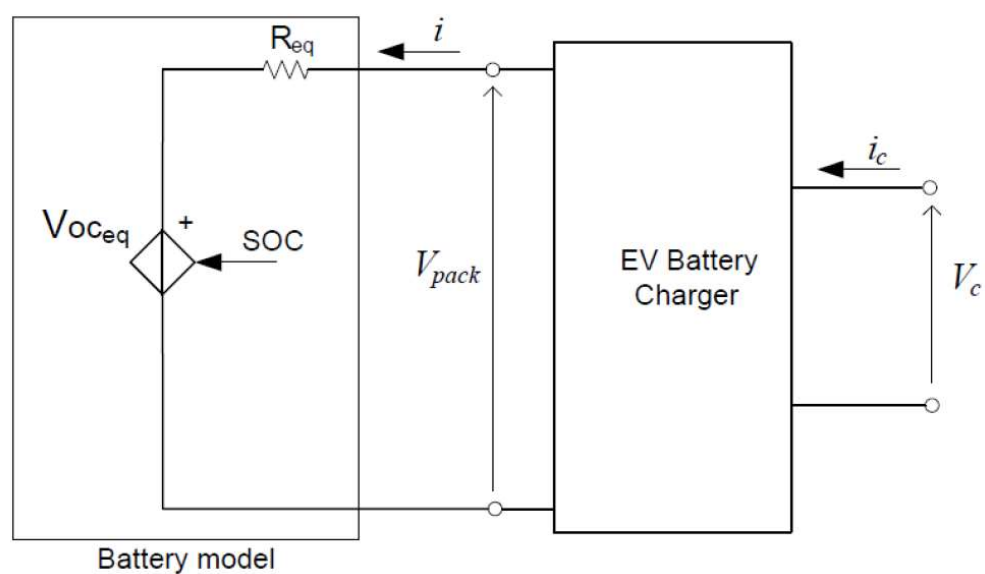

Fig. 1. Simplified electric scheme of the car battery and charger [18] 


\subsection{Battery charging characteristics}

Electric The standard battery charging scheme for lithium-ion cells used in electric vehicles consists of the Constant Current and Constant Voltage phases and is commonly known as $\mathrm{CC} / \mathrm{CV}$ charging. In the $\mathrm{CC}$ phase, a constant current is maintained on the battery side until the nominal voltage of the cell is reached. During this time, the charging power, which is the product of the charging current and the cell voltage, increases until reaching the maximum when switching from $\mathrm{CC}$ to $\mathrm{CV}$ phase. The charge level of the cell (State of Charge, hereinafter: SOC) increases linearly during this charging phase. In the constant voltage range the nominal voltage of the cell is maintained. In this time, the charging current is reduced, and thus the charging speed of the cell decreases. Charging ends when the full cell capacity is reached.

The most important parameter from the point of view of the power system is the charging power. Assuming the indications from Fig. 1, we can describe the power of charging the battery as:

$$
P_{d c}=V_{p a c k} \cdot i
$$

However, the power consumed from the network can be expressed in the form:

$$
P_{a c}=V_{c} \cdot i_{c}
$$

Power on the network side is greater than charging power due to the efficiency of the charger, and the relationship between them can be described as:

$$
\eta=\frac{P_{d c}}{p_{a c}}
$$

It is worth noting that the voltage on the battery side is directly dependent on the level of charge SOC. The current on the battery side in the CV charging area also depends on the SOC level. It can therefore be concluded that the power on the side of the battery is a function of the level of its charge:

$$
P_{d c}(S O C)=V_{p a c k}(S O C) \cdot i(S O C)
$$

As the voltage in the power network is unchangeable, the charging power on the network side can be expressed in the SOC function as follows:

$$
P_{a c}(S O C)=V_{c} \cdot i_{c}(S O C)
$$

In the charging area at constant current, the controlled value, kept constant by the controller, is the current. The voltage increases as the level of charge increases, until the nominal voltage is reached and the CV charging area is reached. Then the charging current, and thus the charging power, ceases to be a controlled 
quantity. This is particularly important in the case of car cooperation in the V2G scheme, where it is particularly useful for the operator of the network or other entity providing services to the operator to stay in the linear area of the SOC. In this case it is easy to model the power delivered to the network, without knowing the non-linear characteristics of charging individual batteries. The linear area for modern lithium-ion batteries ranges from about $50-60 \%$ to about $90 \%$ of the full battery charge. For the purpose of this work, an approximate course of the battery charging curve was determined, which will then be used in the calculation model (see Fig. 2).

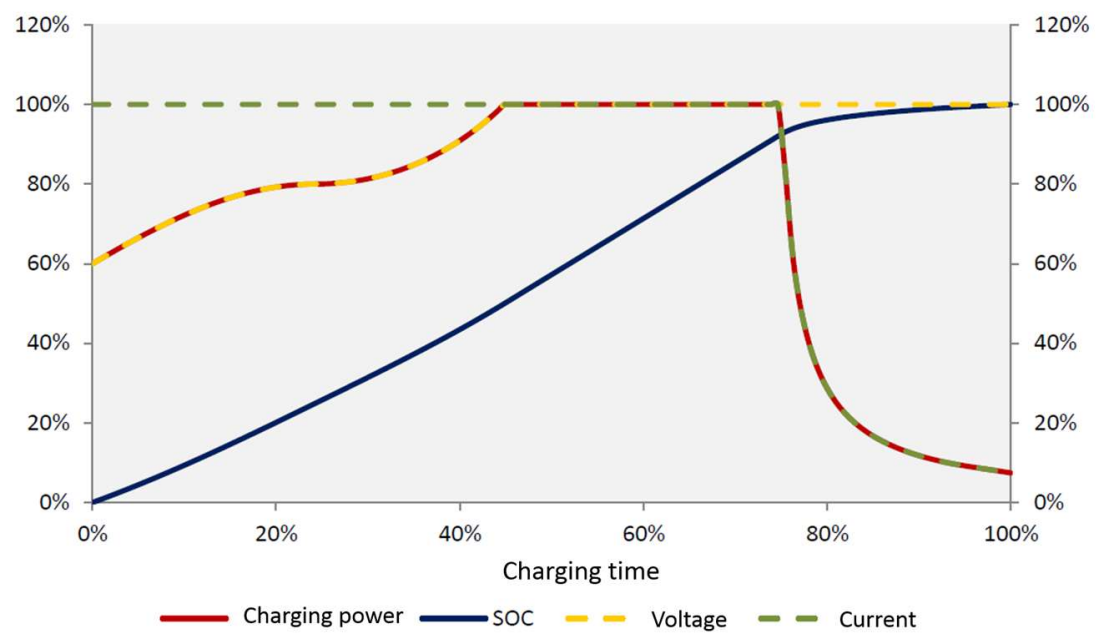

Fig. 2. Charging curve of the battery used in the calculation model

\section{MODEL DESCRIPTION}

\subsection{Construction of a model simulating the load of the power system}

In order to more accurately examine the possible impact of electric cars on the load on the power network, a model simulating additional electricity demand from charging electric vehicles was programmed.

The purpose of the created model was to be the most accurate reproduction of the real conditions for the use of electric vehicles in 2025 (the nationwide target for electromobility was set for this year) and comparing the resulting electricity demand values with historical load data for the electricity grid. To achieve this goal, it was necessary to provide the model with many statistical data from the studies of Polish, German and British statistical offices and research units. The model has been constructed in $\mathrm{R}$ language, due to the possibility of handling large data sets based on libraries adapted for this purpose. 
Using the model, analyzes of additional power demand were carried out on the national and Warsaw scale. Both PSE (national transmission system operator) and Inogy Stoen Operator (distribution system operator in Warsaw) provide data on the power demand in the system in 15-minute granulation. As the simulation result was to be compared with the above data, the model was designed to perform simulations at 15-minute intervals. The remaining input data constituting the input to the model were adjusted to this granulation.

\subsection{Input data for the model of the National Power System}

First of all, the simulation of the power system load in a wide scale covering the entire country was performed. It can be expected that the impact of electromobility on the scale of the entire national system will be smaller than in cities experiencing a proportionally larger increase in the number of electric cars. The results of the model are to provide confirmation of this assumption.

First, data on the power demand in the national power system, published by PSE [19], was developed. To ensure coherence of the approach, both in the case of domestic and Warsaw simulations, historical data were used in the range from 2010 to 2016 (only for these full years data for the Warsaw distribution area are available). Being aware of the variability of electricity demand during the year, four basic periods for which simulations were conducted were distinguished: summer workday, summer day off, winter workday and winter day off (see Fig. 3).

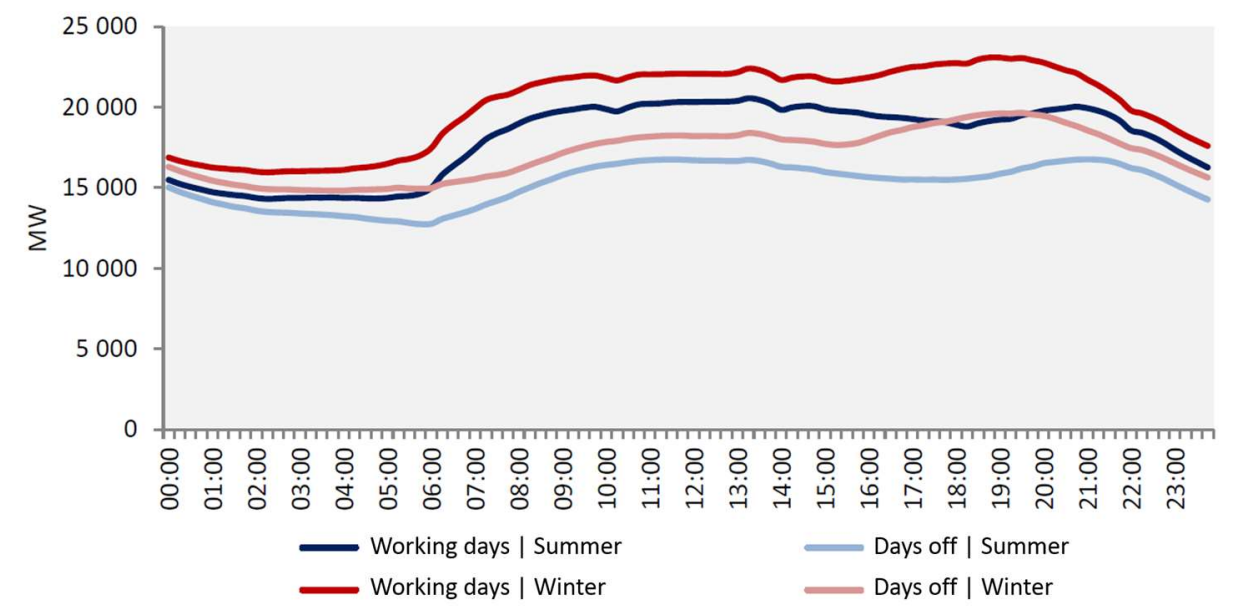

Fig. 3. Curve of daily power demand in the national power system (based on [19])

Limiting up to four different types of days avoids unnecessary fragmentation of data, and at the same time provides a good representation of the variability of network load on an annual and weekly basis. Free days include weekends and 
public holidays. Then, it is possible to notice a significant reduction in power demand. The winter season includes six months with the lowest average daily demand for power, which are the months from October to March. The summer season covers the months from April to September.

\subsection{Input data for the model of the Warsaw distribution area}

The expected impact of charging electric cars on the local power system in cities being the main centers for the development of electromobility is greater than in the case of the analyzed domestic case. Warsaw was selected for comparative purposes due to the possibility of obtaining data about the power demand relatively simply. The area of the capital city is excluded from the territory divided between four large distribution system operators. The operator of the distribution system in Warsaw and its vicinity is Innogy Stoen Operator.

Similarly to the national system, data from the Warsaw network were divided into four types of days (see Fig 4).

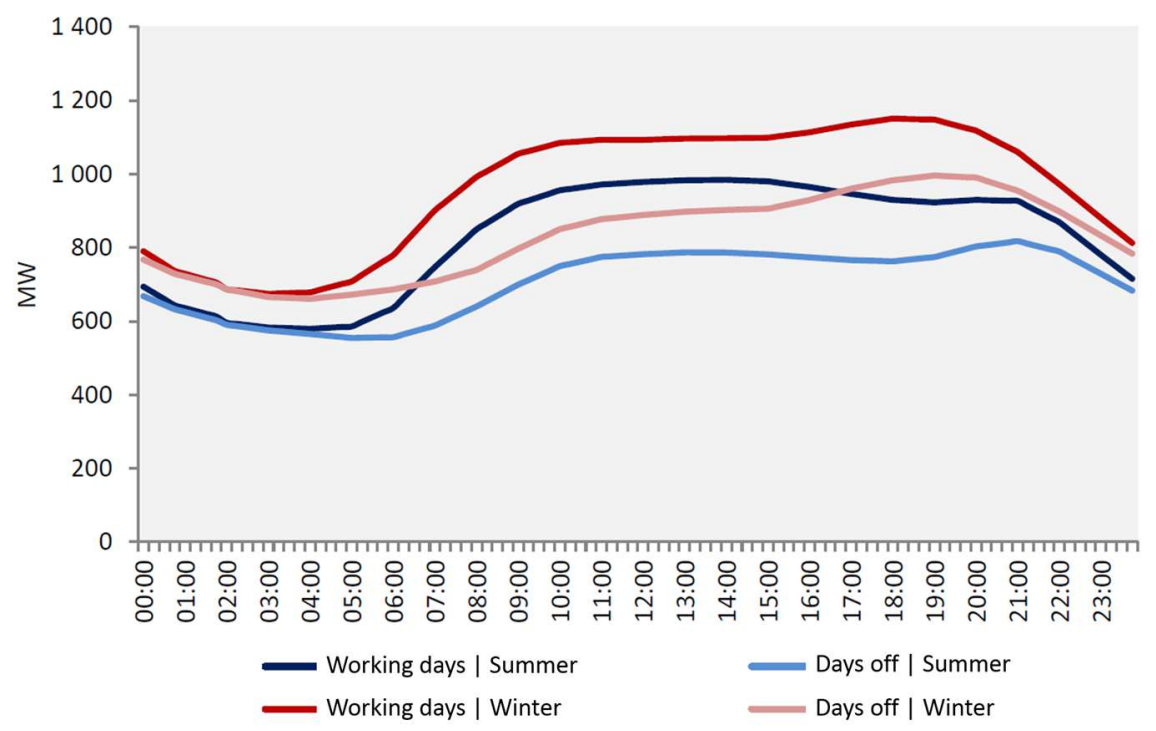

Fig. 4. Curve of daily power demand in the Warsaw distribution area (based on [20])

Observations made for load curves in the national power system are also valid for the local distribution area in Warsaw. Similarly, the differences between the summer and winter seasons, working and free days as well as the shift of evening peaks in the summer and the extension of the night valley on weekends are noticeable. Similarly as in the case of the national system, also for Warsaw a simulation of additional network load was performed, divided into four characteristic types of days. 


\subsection{Statistical data}

In addition to historical data from power system operators, the input into the model also includes various statistical data. Unfortunately, there is no extensive research into the mobility of the society in Poland. For this reason, a large part of the data comes from tests carried out in Great Britain and Germany. It can be assumed that data collected in those countries where car culture is not significantly different from Polish (as opposed to mobility culture, eg in the USA) is better input than assumptions resulting from own experience or imprecise national data.

Using the data of experimentally tested distributions, it is reasonable to simulate the load induced by individual cars and the aggregation of the given output, which is the additional power demand. Aggregation of input data into sets revealing specific values of particular features would be associated with the unambiguous assignment of such sets of characteristics, such as travel duration, daily number of trips, travel time, etc. Such aggregation could, however, contribute to the disruption of final results due to the small number of possible to achieve the value of individual features, so that their distribution cannot be described in the form of an equation and enforces the use of discrete values with the probability assigned to them.

At the stage of data preparation, four separate categories of input data can be distinguished. The first one was to simulate the way cars are used, taking into account statistical data and distributions obtained from them. These include data such as the number of trips during the day, the time of departure and the duration of the journey. The next category is related to the availability and type of chargers for electric cars. In the next stage, a charging curve for lithium-ion batteries developed for the needs of the model was used along with the probability distribution of their charge at the moment of launching the model. The last part of the script responsible for data preparation was designed to reflect the parameters of various types of electric cars, including battery capacity, available charging power, unitary electricity consumption and their market share.

The individual input data for the model and their source are presented below.

1. Number of trips during the day [21]

2. Time of departure [22]

3. The duration of the trip [21]

4. Availability of chargers [23]

5. Battery pre-charge curve - In order to maintain the maximum battery life of lithium- ion batteries, it is assumed that the preferred battery charge will be the SOC range between $60 \%$ and $90 \%$

6. Distribution of electric cars PHEV (Plug-in Hybrid Electric Vehicle) and BEV (Battery Electric Vehicle) - for testing on real data, five most popular PHEV and BEV car models in Europe were used [24]. 


\subsection{Other assumptions}

The model simulated the situation in 2025 , due to the fact that targets for the number of electric cars in Poland were set for this year. On a national scale, it is supposed to be 1 million vehicles with electric drive (PHEV or BEV type). Due to the lack of targets at the level of individual cities for 2025, Warsaw assumed the proportional share of 2020, resulting in a simulated number of electric cars on the streets of Warsaw is 104630 .

Due to the possibility of choosing different paths for the development of electromobility in Poland, the research was carried out for three levels of fully electric cars (BEV) in general electric cars (sum of BEV and PHEV): 0\%, 50\% and $100 \%$.

Due to the issues of battery life raised previously in the text, it was assumed that the range of SOC achievable for each car is $20 \%-90 \%$. This assumption aims to approximate the conditions of using lithium-ion batteries to real ones. What's more, the assumption of $95 \%$ efficiency of the charging-discharging cycle for the lithium-ion battery was assumed. This level is currently the maximum achievable ceiling, but it can be assumed that with the technological development the average battery efficiency will be close to this value. The second factor increasing the actual production of electricity, compared to its consumption by chargers, is the transmission energy losses. The model assumes that they can reach up to $10 \%$. Therefore, the total efficiency with which the energy generated in the power system is used in the batteries of electric vehicles is $\eta=95 \% * 90 \%=85.5 \%$.

\subsection{Simulation methodology}

As part of this work, two models were prepared simulating the impact of electric vehicles battery charging on the load of the power system. The first one assumes passive implementation of electric car technology, which will manifest itself in the lack of systemic changes that facilitate their integration into the network. In the second scenario, changes are being introduced in the form of creating incentives to shift the charging of electric vehicles to hours of valleys of 24-hour power demand in the power system.

As previously mentioned, the first part of the model is to prepare the batch data in the appropriate form for the mathematical model. The following values of variables whose introduction is required by the program are the same for both scenarios:

a) Number of cars:

- $1,000,000$ cars for the national model

- 104,630 cars for the Warsaw model

b) Number of days:

- 8 days - the decision was made to simulate the whole week in 15 -minute granulation. Thanks to this approach, it is possible to analyze changes in 
the scope of the day on one set of output data, as well as conduct case analysis for the entire week and obtain averaged values for a weekday ( 5 days) and free day ( 2 days). The model was adopted 8 days as an input value to allow the output from the first day to be cut off. This is done in order to get rid of distorted results for the first 15-minute simulation periods, during which the model strives to stabilize, ie to achieve a situation in which the results from the next days are comparable.

c) The first day of simulation

- Sunday - the last day of the week was selected, because as the first day of entry into the model it will be finally cut off in the preparation phase of the results. As a result, the model will return the result in the form of an additional load distribution from 00:00 on Monday (adopted as the beginning of the first 15-minute interval on Monday) to 23:45 on Sunday (adopted as the beginning of the last 15-minute interval on Sunday). This format of results seems to be the most intuitive in further analysis.

d) BEV car share - three levels were adopted for analysis:

- $0 \%$

- $50 \%$

- $100 \%$

e) Season

- Summer - specific energy consumption has been assigned according to the energy consumption in summer

- Winter - specific energy consumption has been assigned in accordance with the energy consumption in winter (assumption of unit energy consumption in winter higher by $25 \%$ than in summer).

Based on the above data, with the help of sampling with the probability resulting from the distributions contained in subsection 3.4, tables are prepared for each car containing the number of journeys, start and end times of individual journeys, the availability of the charger during each car stop and the type of charging that this it offers. Next, for each car are assigned technical parameters, taking into account their probability distributions. Obviously, in the case when a car without fast charging has access to a quick charger, such charging is not carried out - then it is assumed that the car can take advantage of slow charging. The above procedure allows to prepare matrices with vehicle states, taking values 0 (journey), 1 (slow charging) and 2 (fast charging). The matrix of the above states assigned to each car in 15-minute intervals constitutes the charge to the second part of the model. The right model algorithm is performed for each vehicle separately. For a given 15-minute time window, the status of the vehicle is read, depending on which the corresponding calculations or value assignments are made. The sizes determined in this part of the model are the level of SOC battery, energy accumulated in 
battery $Q$ and energy change in a given time window $d Q$. In addition to the vehicle state matrix, the $\mathrm{SOC}_{0}$ level is also known at the time the calculations begin, and thus the value of $Q_{0}$.

\subsection{Algorithm of basic simulation}

The basic simulation assumes maintaining the status quo in the field of cooperation between the electricity consumer and the network, which results in lack of incentives for charging electric vehicles in the daily valleys of power demand in the power system. In this case, it was assumed that users will want to charge electric vehicles immediately after the end of the journey. As a result, the car's charge level would be kept as high as possible. On the other hand, loading the car after each trip will be a troublesome act and users of cars tend to charge them during longer, scheduled stops of the vehicle. For this reason, the loading of vehicles during the stopping process lasting less than 2 hours in the case when the SOC level exceeds $50 \%$ has been eliminated in the model.

In the case of status 0 , which means vehicle travel, the algorithm performs the following actions:

$$
d Q_{i}=Q_{i+1}-Q_{i}=-q \cdot s
$$

$d Q \quad$ change of the energy value accumulated in the battery between the end and the beginning of the time window,

$q \quad$ unit energy consumption $[\mathrm{kWh} / \mathrm{km}]$,

$s$ the distance traveled by the car in the time window $(10 \mathrm{~km} / 15 \mathrm{~min}$ accepted in the model)

$$
S O C_{i+1}=\frac{Q_{i+1}}{Q_{\max }}
$$

SOC battery level [\%],

$Q_{\max }$ maximum amount of energy that can be stored.

If in a given time window the algorithm returned the SOC value below $20 \%$, the trip was forced to end. In line with previous considerations, the minimum SOC value that should be reached for batteries has been set at $20 \%$. The final charge state of the SOC in this time window is $20 \%$.

For state 1, corresponding to a standstill lasting at least 2 hours, with the possibility of slow charging or a standstill of less than 2 hours in the case when the battery charge is lower than $50 \%$, the following actions were performed: 


$$
S O C_{i+1}=f\left(S O C_{i}, \frac{15 \min }{T_{\text {max }}^{P_{\text {slow }}}}\right)
$$

$T_{\max }^{P_{\text {slow }}} \quad$ change of the energy value accumulated in the battery between the end and the beginning of the time window.

The $\mathrm{SOC}_{\mathrm{i}+1}$ value was determined based on the generated battery charging profile. Knowing the $\mathrm{SOC}_{\mathrm{i}}$ value and the ratio of the length of the 15-minute interval to the time of full battery charging.

$$
\begin{gathered}
Q_{i+1}=S O C_{i+1} \cdot Q_{\max } \\
d Q_{i}=Q_{i+1}-Q_{i}
\end{gathered}
$$

If $90 \%$ of the maximum battery charge is reached, the algorithm forces the charging to end.

For state 2, corresponding to a standstill of at least 2 hours, with the possibility of quick charging or parking less than 2 hours in the case when the battery charge is lower than $50 \%$, actions were carried out analogically to the previous case:

$$
S O C_{i+1}=f\left(S O C_{i}, \frac{15 \mathrm{~min}}{T_{\text {max }}^{P_{\text {fast }}}}\right)
$$

$\mathrm{T}_{\max }^{\mathrm{P}_{\text {fast }}} \quad$ fast battery charging time from $\mathrm{SOC}=0 \%$ to $\mathrm{SOC}=100 \%$,

The $\mathrm{SOC}_{\mathrm{i}+1}$ value was determined based on the generated battery charging profile. Knowing the value of $\mathrm{SOC}_{\mathrm{i}}$ and the ratio of the length of the 15-minute interval to the time of full battery charging, you can determine the state of charge at the end of the 15-minute loop window.

$$
\begin{gathered}
Q_{i+1}=S O C_{i+1} \cdot Q_{\max } \\
d Q_{i}=Q_{i+1}-Q_{i}
\end{gathered}
$$

If $90 \%$ of the maximum battery charge is reached, the algorithm forces the charging to end.

In the event that the stop lasted less than 2 hours and the SOC exceeded 50\%, no calculations were carried out and the following values were attributed:

$$
S O C_{i+1}=S O C_{i}
$$




$$
\begin{aligned}
& Q_{i+1}=Q_{i} \\
& d Q_{i}=0
\end{aligned}
$$

For each of the above cases, the change of the energy value accumulated in the battery between the end and the beginning of the ith time window $d Q_{i}$ has been converted into the value of the additional power demand $P_{i}$.

$$
P_{i}=\frac{\sum_{n=1}^{n_{\max }} d Q_{i}}{\frac{1}{4} h}
$$

$n_{\max }$ the number of cars for a given case.

\section{RESULTS}

\subsection{The basic model for the national power system}

The calculations were carried out for three levels of the share of BEV cars in the electric car market, for a period of 7 days, starting from Monday. The results were presented graphically in Figures 5-7.

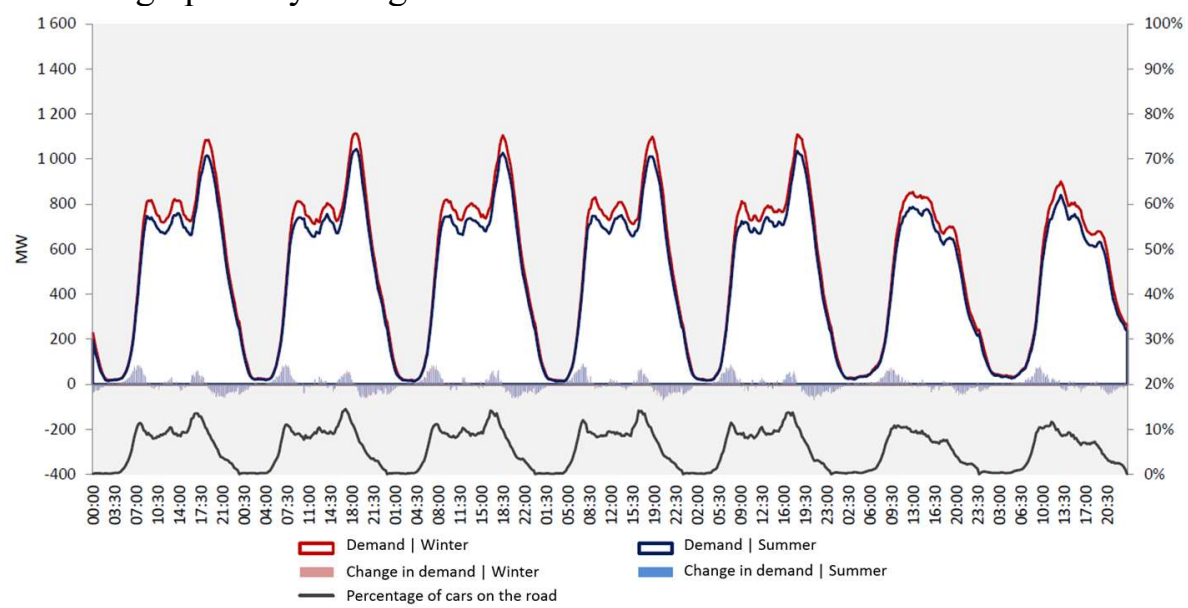

Fig. 5. Time distribution of the demand for power caused by charging electric vehicles for basic model in case of the national power system assuming a BEV share equal to $0 \%$ Analysis of the daily travel profile allows for preliminary validation of the model's results. The power demand curve turns out to be slightly shifted in time relative 
to the travel curve. Demand in the winter season exceeds the summer values due to the higher unit energy consumption of electric cars in winter. Free days are characterized by clearly lower additional demand, which is the effect of a lower number of trips on these days.

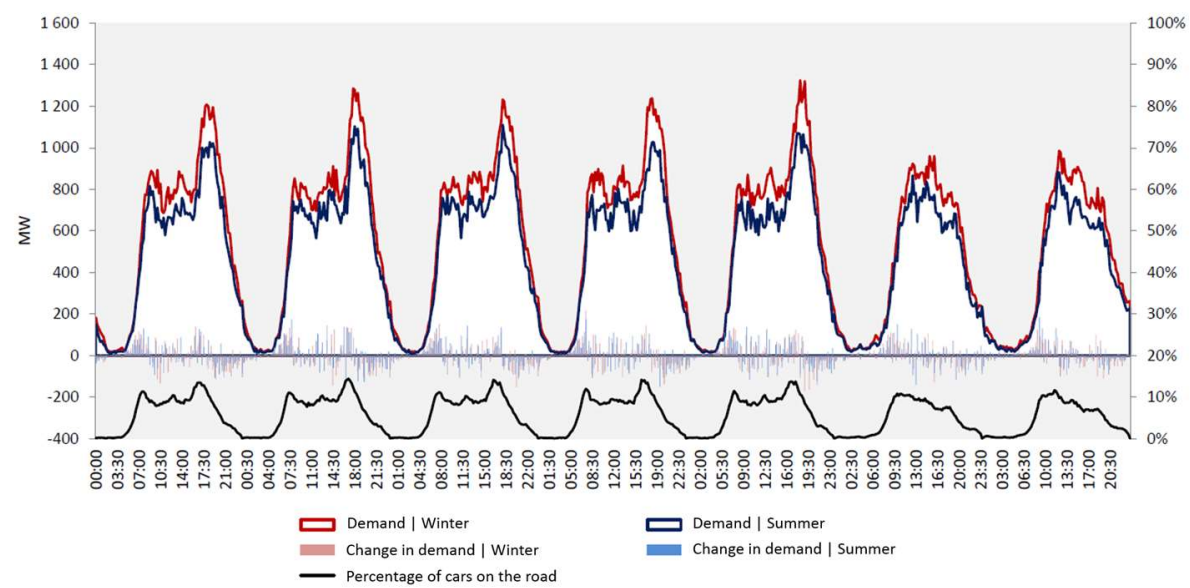

Fig. 6. Time distribution of the demand for power caused by charging electric vehicles for basic model in case of the national power system assuming a BEV share equal to $50 \%$

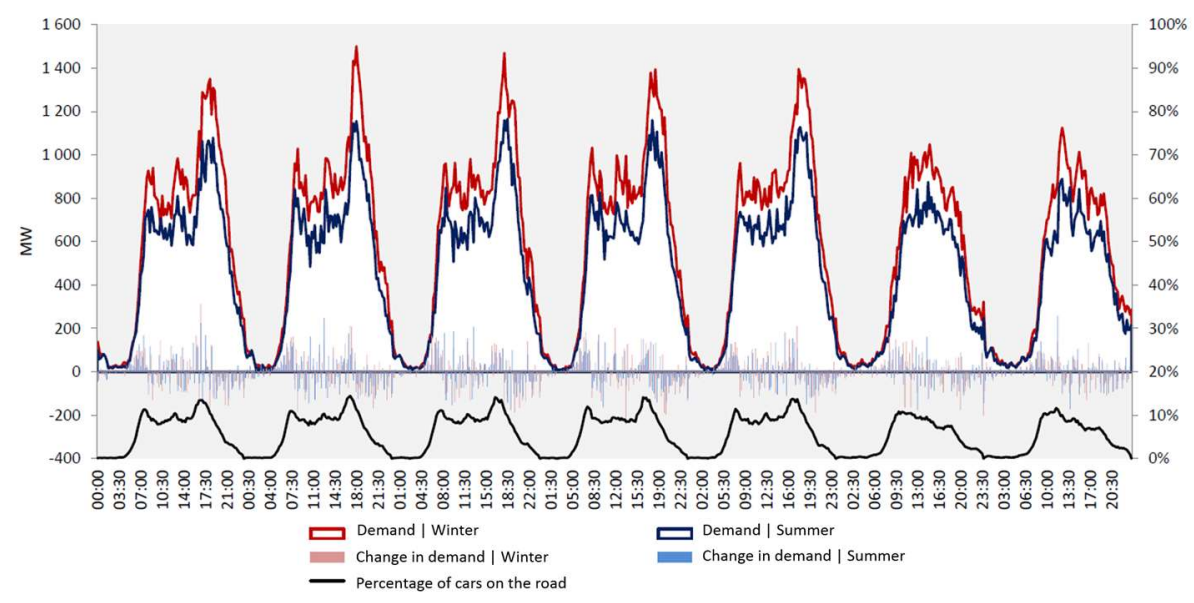

Fig. 7. Time distribution of the demand for power caused by charging electric vehicles for basic model in case of the national power system assuming a BEV share equal to $100 \%$

The average demand for power resulting from the charging of electric cars is 548 MW on weekdays and $431 \mathrm{MW}$ on non-working days. However, the additional power requirement is not evenly distributed. In each of the analyzed cases, it can 
be seen that the peak of demand on weekdays falls on evening hours, coinciding with the largest daily demand for power in the national system. On free days, the highest demand was observed in the afternoon. For the zero share of BEV $(100 \%$ share of PHEV cars) among electric cars, the maximum chargers demand for power reaches about $1100 \mathrm{MW}$ in winter and $1000 \mathrm{MW}$ in summer, while for a hundred percent share of BEV it grows to $1500 \mathrm{MW}$ in winter and less than 1200 MW in summer.

From the point of view of network stability and working conditions of generation sources, the dynamics of changes in power demand is important. When the fleet of electric cars is composed only of PHEV cars (Fig. 5), the chart is smooth and the periods of increases and decreases of the demand are reproducible and smoothly changing. On weekdays, the first increase in demand falls on the morning hours - after arriving at work. With small fluctuations, demand continues until return home from work, when there is another increase in chargers power consumption. From now on, there is a continuous decline to the early hours of the morning. On the days off, the largest increases in power take place after traveling around midday. The highest positive dynamics of change in the total power demand is observed in the morning and reaches around $90 \mathrm{MW} / 15 \mathrm{~min}$. The biggest drops are recorded in the evening and reach values above 70MW/15 min. For the case of the maximum share of BEV cars, the appearance of the curve is clearly changing (see Fig. 7). It is ragged, which indicates a sudden, abrupt change in the demand for power to charge electric cars. The explanation of this phenomenon is a short time of fast charging combined with high power consumed from the network during this process. The rapidly changing number of cars loaded in this case has a much greater impact on the network than in the previously discussed example. The disadvantageous effect of such a structure of electric cars on the network can be observed by comparing the rate of change in power. For the $100 \%$ share of BEV, they show greater randomness and higher absolute values. Transitions between individual time windows are not smooth which indicates high demand volatility. The maximum increases recorded for this case are even above $300 \mathrm{MW} / 15 \mathrm{~min}$, and drops above $250 \mathrm{MW} / 15 \mathrm{~min}$, although it is possible that the rate of change observed in shorter intervals would be even higher.

The results for the case with equal share of PHEV and BEV cars are between the two situations described above. Due to the initial phase of development of electromobility in Poland and the unpredictable further development of the domestic electric vehicle market, the option of PHEV and BEV's participation in the amount of 50/50 will be accepted for further analysis of the impact on the domestic electric power system. This will allow for averaging the obtained results and avoiding extreme scenarios that are not very achievable.

Due to the stabilization of the demand for electricity in recent years, the historical data from 2010-2016 were adopted for the analysis for 2025. The results presented 
in Figures 8 and 9 show the share of power consumed by the chargers in the total domestic demand in the summer. It is visible that they account for a small portion of the total demand - it is a maximum of $5.6 \%$ on a weekday and $5.1 \%$ on a day off. It can also be noted that system load will occur mainly during the day, while at night the demand increase will approach zero.

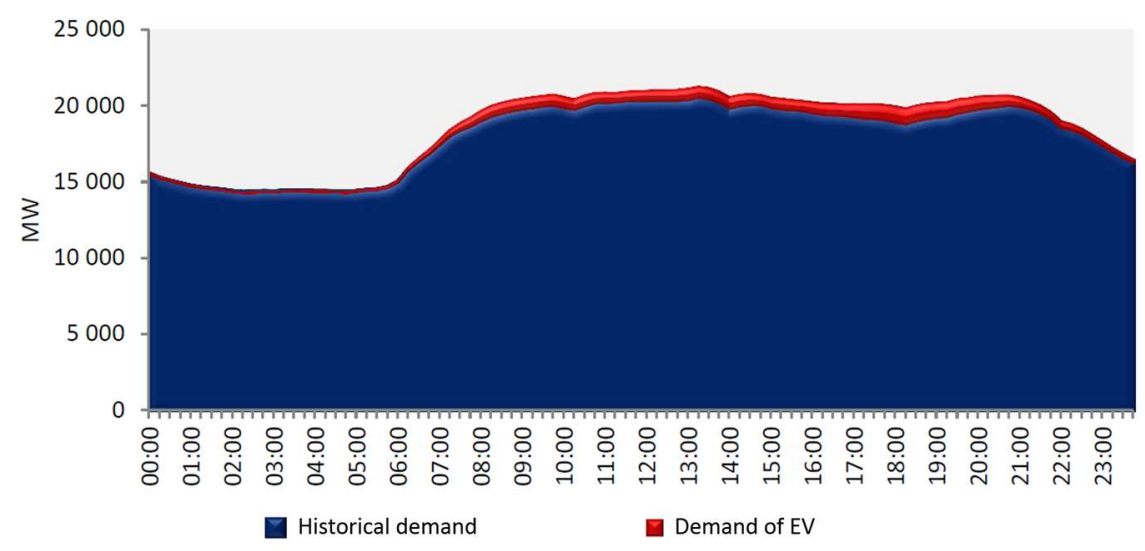

Fig. 8. Daily power demand in Poland for the summer working day including charging electric cars in the basic model

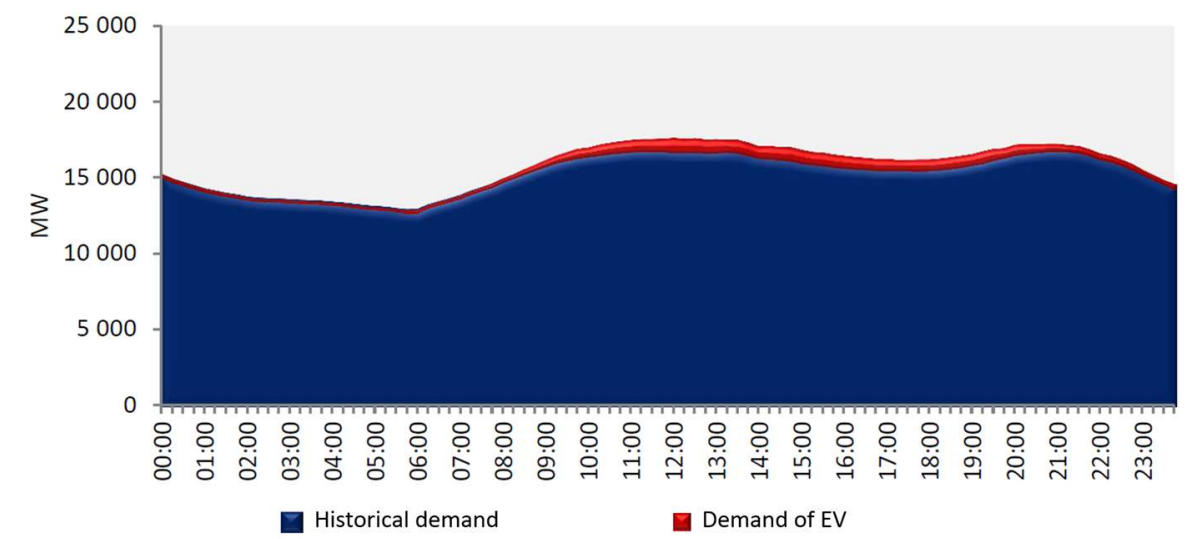

Fig. 9. Daily power demand in Poland for the summer day off including charging electric cars in the basic model

There will therefore be an increase in the differences between the daily valley and the peaks of demand. It results from the lack of incentives to shift charging in time and is an unfavorable factor from the point of view of the network operator and generation sources, causing, among others, higher values of power changes over time, as well as a lower rate of utilization of installed capacity in the system, 
resulting from greater daily irregularity of the load distribution. The situation in the winter period is presented in Figures 10 and 11. It is analogous to the situation during the summer. The share of electric car chargers in total power consumption is in this case a maximum of $5.5 \%$ and $5.3 \%$ for working and free day, respectively.

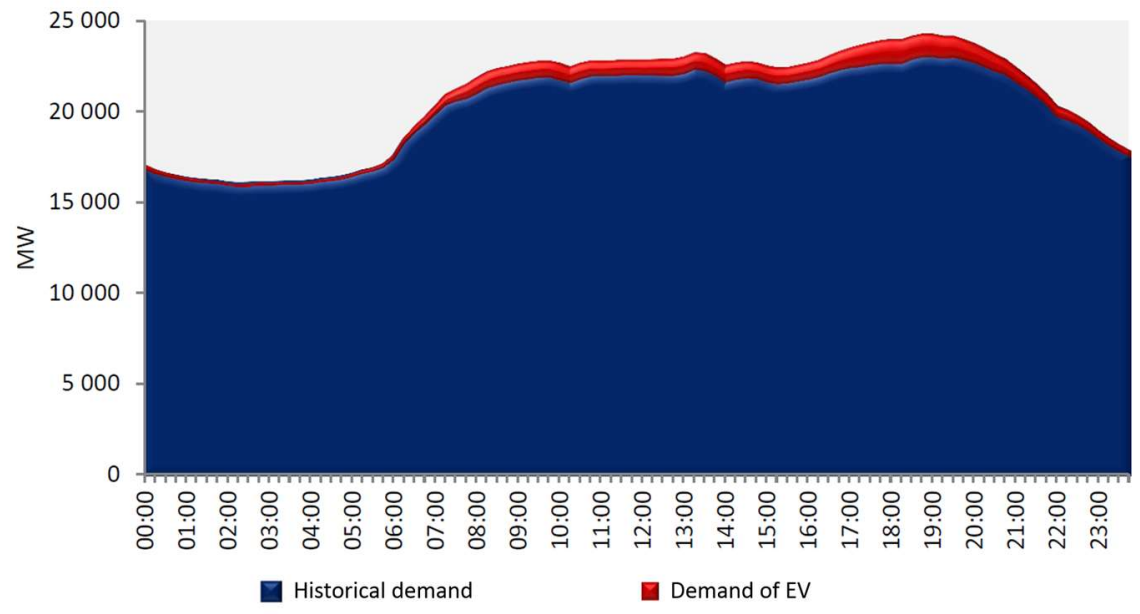

Fig. 10. Daily power demand in Poland for the winter working day including charging electric cars in the basic model

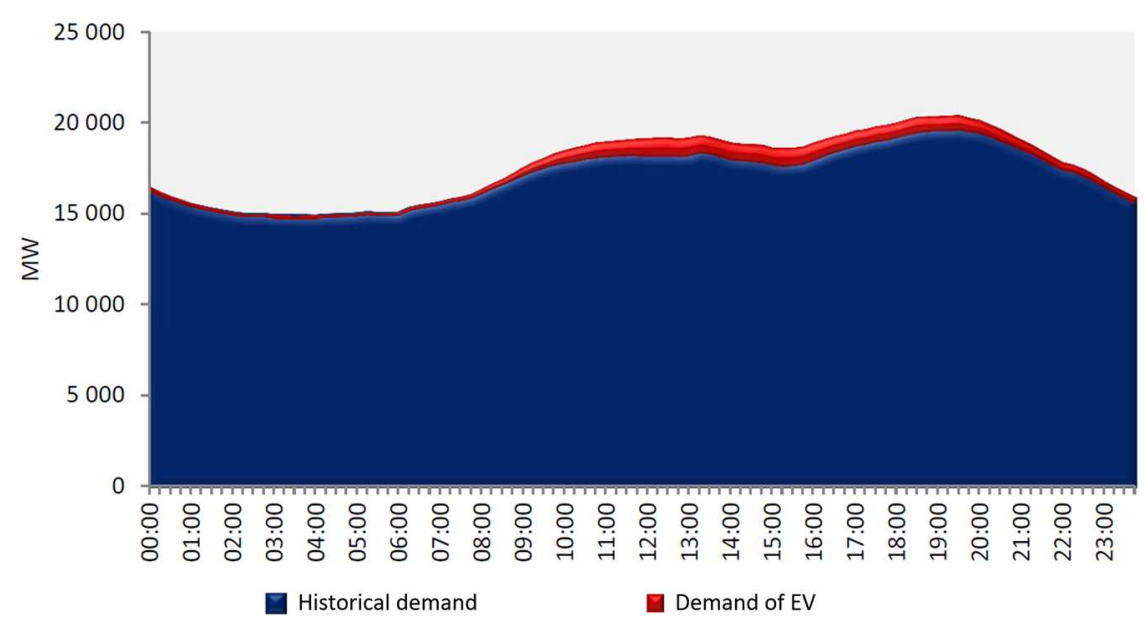

Fig. 11. Daily power demand in Poland for the winter day off including charging electric cars in the basic model

For the purpose of comparison, the additional electricity demand per year was also estimated based on the calculation model. With data on power demand in 15- 
minute intervals and the number of individual types of days in a year, it is easy to calculate the system load of EV chargers for the whole year. In the table below, the average number of occurrences for 2010-2016 is assigned to each type of day. Based on the above data and the results of the weekly model, the result can be calculated as follows:

$$
\Delta E=\sum_{i=1}^{4} \sum_{t=1}^{96} P_{a v}^{i, t} \cdot \frac{1}{4} h
$$

$t$ ordinal number of the time window,

$\mathrm{P}_{\mathrm{av}}^{\mathrm{i}, \mathrm{t}}$ the average power value for the $\mathrm{i}$-th category of the day in the $\mathrm{t}$-th time window.

The additional electricity demand estimated in Poland for one million electric cars in use would amount to $4.41 \mathrm{TWh}$ compared to $4.3 \mathrm{TWh}$ forecasted in the Ministerial Development Plan for Electromobility.

\subsection{The basic model for the Warsaw area}

The analysis of changes caused by electromobility in Warsaw presents similar conclusions as for the national system. The main difference between the situation of both systems is the greater share of electric cars in the total number of cars in a given area, which implies a greater share of energy collected by EV loaders in total demand.

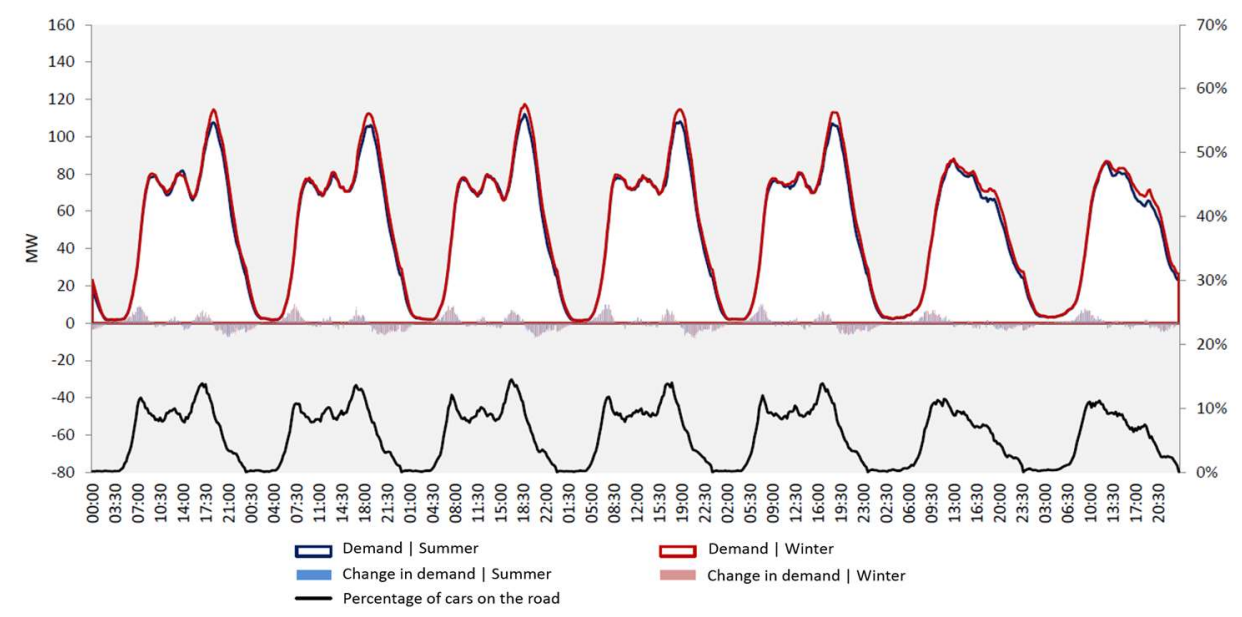

Fig. 12. Time distribution of the demand for power caused by charging electric vehicles for basic model in case of Warsaw area assuming a BEV share equal to $0 \%$ 


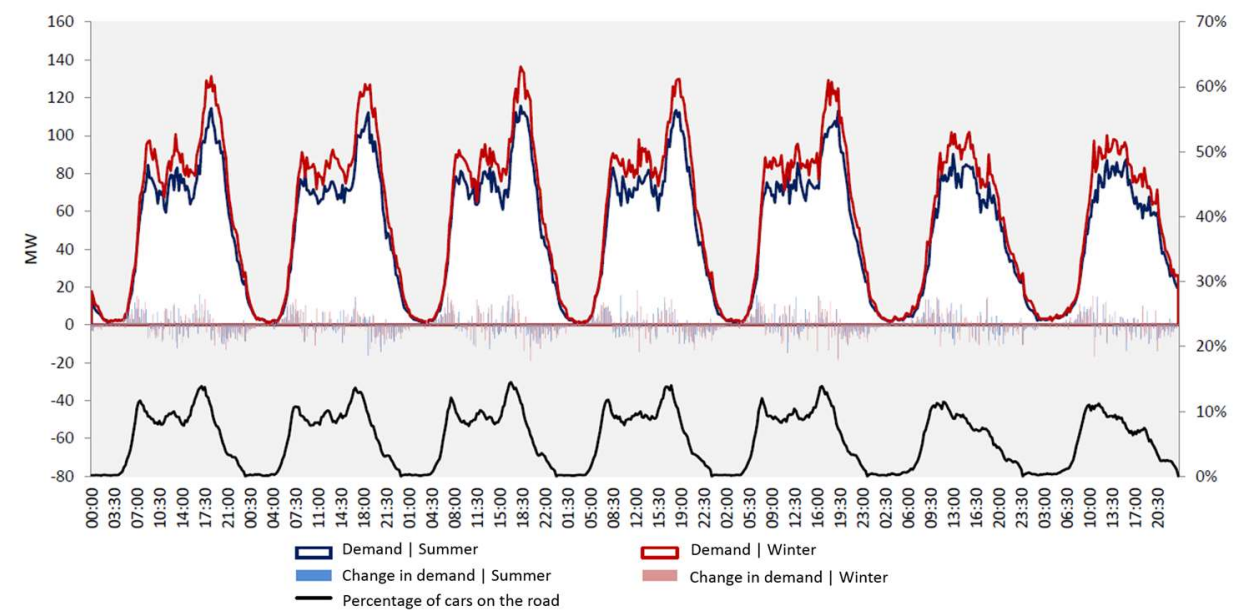

Fig. 13. Time distribution of the demand for power caused by charging electric vehicles for basic model in case of Warsaw area assuming a BEV share equal to $50 \%$

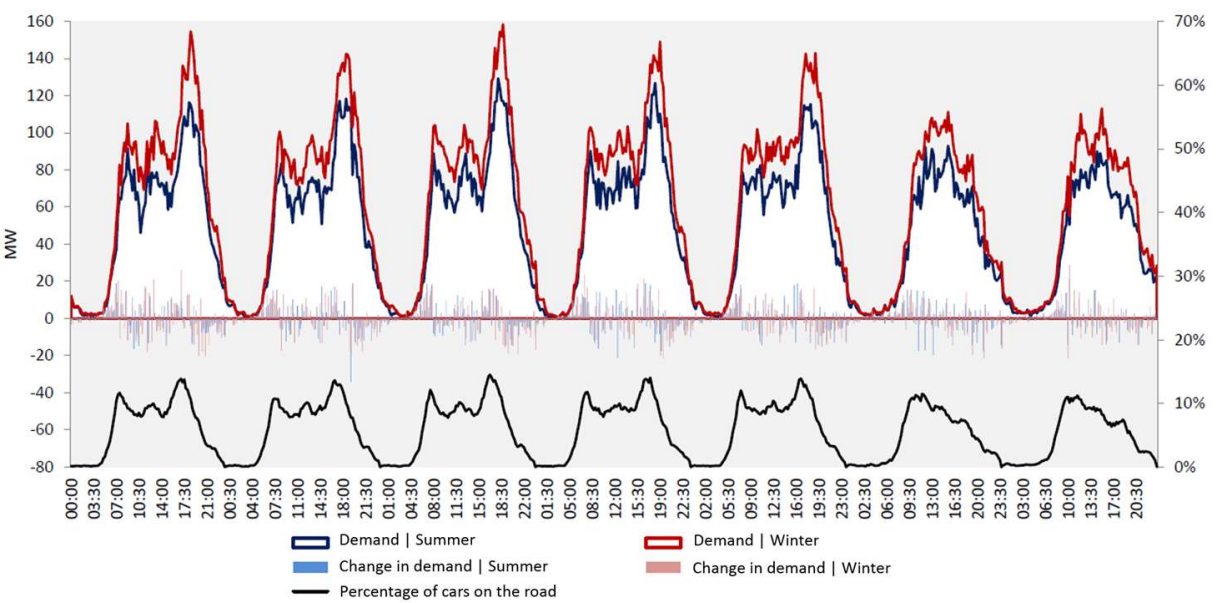

Fig. 14. Time distribution of the demand for power caused by charging electric vehicles for basic model in case of Warsaw area assuming a BEV share equal to $100 \%$

From the analysis of the seven-day periods for different BEV shares in general electric cars, identical conclusions can be drawn as for the national case. The increase in saturation of the market with fully electric cars worsens the grid's working conditions, introducing greater load variability and higher nominal values of its increments and decreases. For example, for the zero share of BEV $(100 \%$ PHEV) in general electric cars, the maximum power increase is $10 \mathrm{MW} / 15 \mathrm{~min}$, and the maximum power drop is around $8 \mathrm{MW} / 15 \mathrm{~min}$. On the other 
hand, for a car fleet consisting of only BEV cars, the parameters discussed are rising to $29 \mathrm{MW} / 15 \mathrm{~min}$ and $34 \mathrm{MW} / 15 \mathrm{~min}$ respectively.

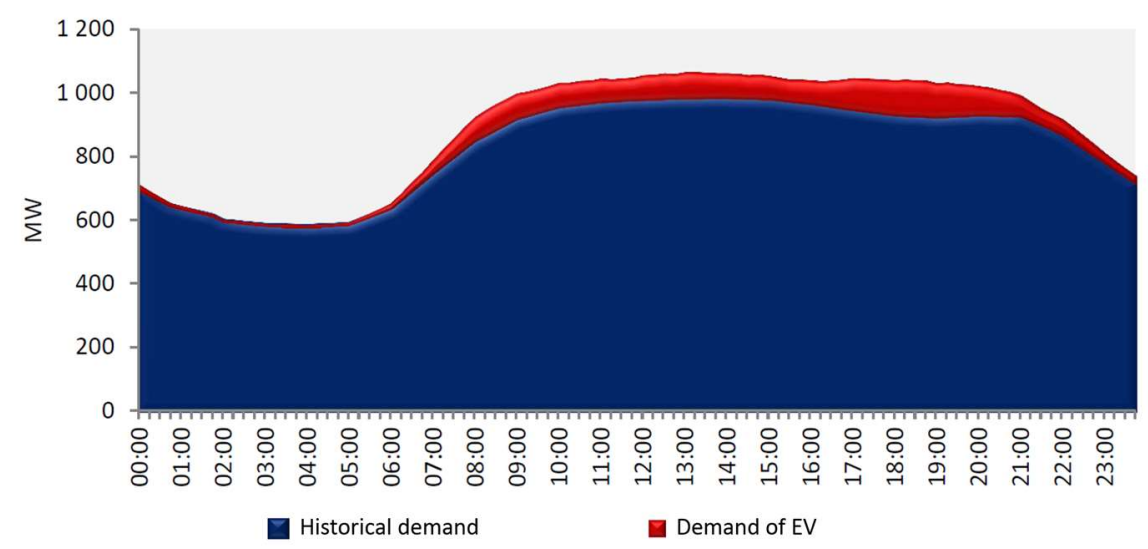

Fig. 15. Daily power demand in Warsaw for the summer working day including charging electric cars in the basic model

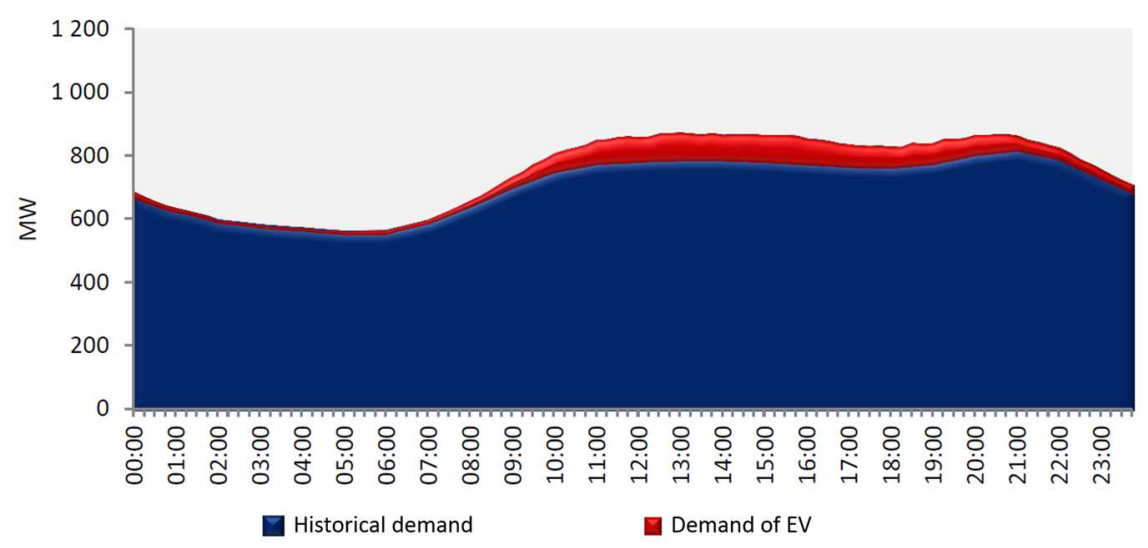

Fig. 16. Daily power demand in Warsaw for the summer day off including charging electric cars in the basic model

The daily analysis shows the greater impact of charging electric cars on the total power consumption from the network. On weekdays it is the highest in the evening peak, and on weekends in the afternoon and reaches about $11-12 \%$ of the total demand. On the other hand, during the night the share of EV charging in the total electricity consumption drops almost to zero. A favorable situation would be if local generation sources were able to develop a rapidly changing demand for power. An example of a source that can compensate for significant power fluctuations can be a newly built combined cycle unit in Żerań CHP. 


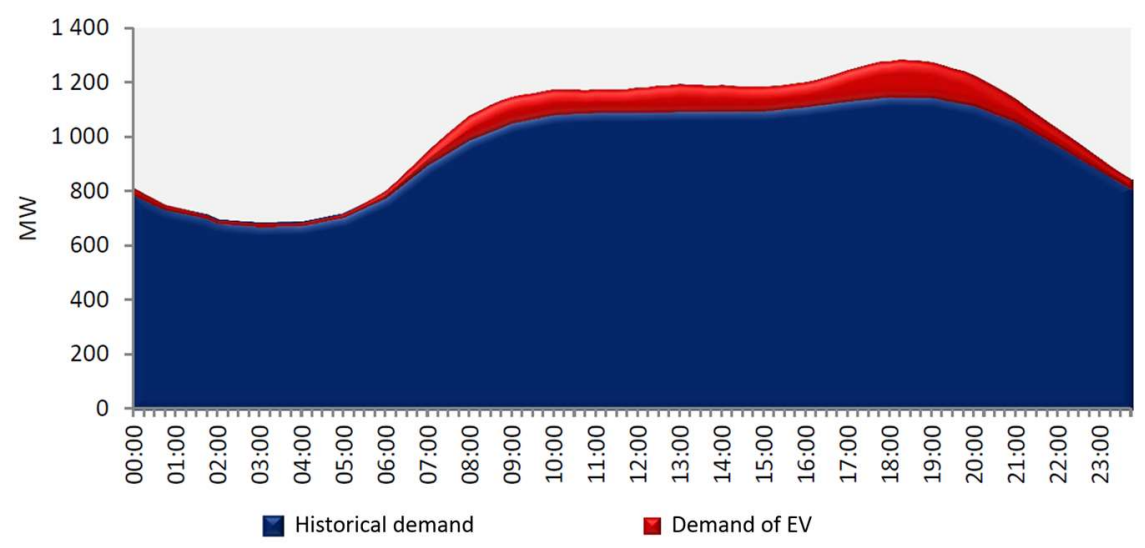

Fig. 17. Daily power demand in Warsaw for the winter working day including charging electric cars in the basic model

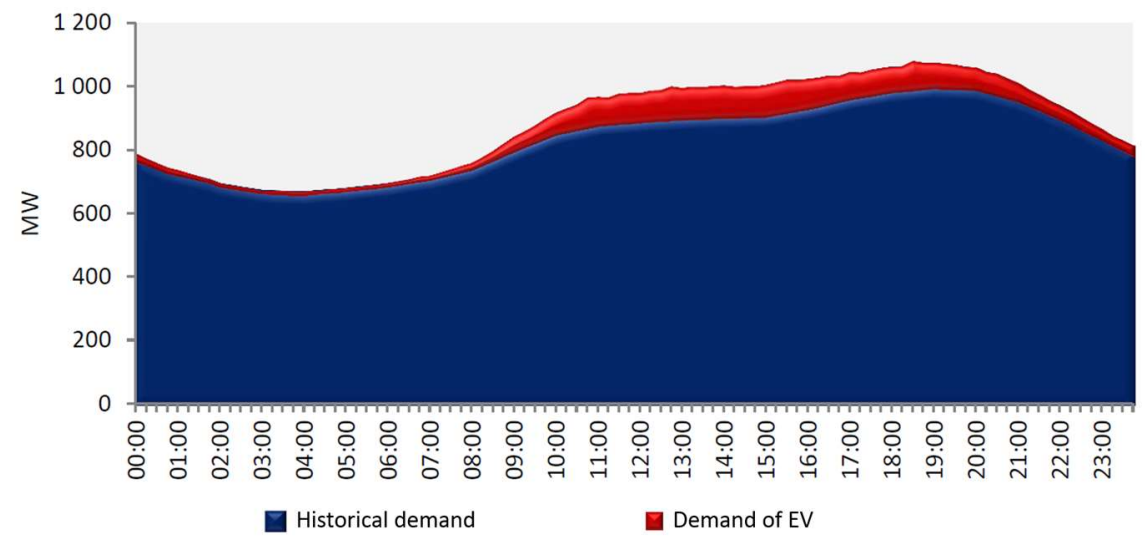

Fig. 18. Daily power demand in Warsaw for the winter day off including charging electric cars in the basic model

\section{CONCLUSIONS}

The promotion of electromobility in Poland seems to be inevitable due to the technological development of the e-mobility industry and the constantly growing benefits of using electric cars. In Poland, a fast growth of the electromobility sector in the following years is expected and a million registered electric vehicles are to be achieved in 2025. The implementation of the proposed act on electromobility and alternative fuels, which establishes the legal framework for the sector, determines the directions of its development and defines goals. 
The planned increase in the number of cars charged with electricity will mean an increase in the demand for power in the national power system, and therefore it seems appropriate to analyze the impact of the development of the electric vehicles industry on the working conditions of the power system. In addition to estimating the total increase in electricity demand, the key issue is the simulation of its potential daily distribution in different scenarios. In order to carry out such an analysis, a computational model was created to estimate the distribution and amount of additional power demand.

Preparing to program the model consisted of conducting analysis of electromobility markets in the leading countries in this field, development of technical data in the field of electric vehicles and their charging infrastructure, as well as obtaining statistical data. Various examples of the development of emobility markets have suggested the need to take into account different scenarios for the development of the structure of the electric car market that differ in the level of market saturation with fully electric cars. Obtained technical data allowed to simulate the charging process of a lithium-ion battery used in electric cars. Statistic data distributions have in turn made it possible to implement different ways of using vehicles. The designed model was used to perform calculations for the national system and for the Warsaw distribution area, where the effect of electromobility development will be correspondingly larger. The simulation was carried out in the basic scenario assuming the maintenance of current system solutions. This analysis will be extended by a progressive scenario in which price incentives for electric car users is programmed.

The results of the model confirm the assumptions about the possibility of a twofold effect of electromobility on the power system load. As a rule, the greater share of BEV cars is accompanied by greater variability of power demand and higher power consumption peaks. The difference between the scenarios manifests itself in the daily distribution of the load from charging electric cars. The simulation indicates a deterioration of the conditions of the generation sources by increasing the demand for power during the day and a small impact on the network load at night, which results in deepening the differences between the daily valley and the peak. Higher load unevenness will adversely affect the use of installed power in the power system. It is expected that in the progressive scenario, assuming the introduction of variable electricity prices, the values of maximum energy consumption from the network will increase and the peak of the load caused by battery charging will shifts to night hours, causing flattening of the daily power demand graph.

The results of the model indicate a non-negligible impact of economic incentives on the distribution of power demand resulting from the charging of electric cars. Depending on the implemented solutions, electromobility can help or harm the power system. The legislator, the power system operator and electricity generators 

VEHICLES ON POWER DEMAND IN THE NATIONAL POWER SYSTEM

should therefore take action to develop system solutions that will encourage users of electric vehicles to load them in a way that benefits them and for the power system operator and owners of power sources.

\section{REFERENCES}

1. European Commission 2010. Communication from the Commission: Europe 2020. A Strategy for smart, sustainable and inclusive growth.

2. European Comission 2011. Directorate-General for Mobility and Transport, White Paper on Transport: Roadmap to a Single European Transport Area: Towards a Competitive and Resource-efficient Transport System. Publications Office of the European Union.

3. European Union 2009. Directive 2009/28/EC of the European Parliament and of the Council of 23 april 2009 on the promotion of the use of energy from renewable sources and amending and subsequently repealing directives 2001/77/EC and 2003/30/EC. Official Journal of the European Union 5.

4. European Commission 2013. Communication from the commission to the european parliament, the council, the European economic and social committee and the committee of the regions. Clean Power for Transport: A European alternative fuels strategy.

5. European Commission 2016. Directive 2014/94/EU of the European parliament and of the council of 22 October 2014 on the deployment of alternative fuels infrastructure. Brussels.

6. Polish Ministry of Energy. Package for Clean Transport [Pakiet na Rzecz Czystego Transportu]. Warsaw.

7. Polish Ministry of Energy 2016. The national policy framework for the development of alternative fuels infrastructure [Krajowe ramy polityki rozwoju infrastruktury paliw alternatywnych]. Warsaw.

8. Polish Ministry of Energy 2016. Electromobility Development Plan in Poland [Plan Rozwoju Elektromobilności w Polsce]. Warsaw.

9. Polish Ministry of Energy 2016. The draft law on electromobility and alternative fuels [Projekt ustawy o elektromobilności $i$ paliwach alternatywnych]. Warsaw.

10. Milewski, J, Wejrzanowski, T, Szabłowski, Ł, Baron, R, Szczęśniak, A and Ćwieka, K 2017. Development of Molten Carbonate Fuel Cells at Warsaw University of Technology. Energy Procedia 142, 1496-1501.

11. Baron, R, Wejrzanowski, T, Szabłowski, Ł, Szczęśniak, A, Milewski, J and Fung, KZ 2018. Dual ionic conductive membrane for molten carbonate fuel cell. International Journal of Hydrogen Energy 43, 8100-8104.

12. Baron, R, Wejrzanowski, T, Milewski, J, Szabłowski, Ł, Szczęśniak, A and Fung, KZ 2018. Manufacturing of $\gamma$-LiAlO2 matrix for molten carbonate fuel 
cell by high-energy milling. International Journal of Hydrogen Energy 43, 6696-6700.

13. Milewski, J, Futyma, K and Szczęśniak, A 2016. Molten carbonate fuel cell operation under high concentrations of $\mathrm{SO}_{2}$ on the cathode side. International Journal of Hydrogen Energy 41, 18769-18777.

14. Chmielewski, A, Mączak, J and Szulim, P 2017. Experimental research and simulation model of electrochemical energy stores. International Conference Automation. Cham, Springer, 236-246.

15. Chmielewski, A, Piórkowski, P, Bogdziński, K, Szulim, P and Gumiński, R 2018. Test bench and model research of hybrid energy storage. Journal of Power Technologies 97, 406-415.

16. Milewski, J, Badyda, K and Szabłowski, Ł 2016. Compressed air energy storage systems. Journal of Power Technologies 96, 245-260.

17. Krawczyk, P, Szablowski, L, Badyda, K, Karellas, S and Kakaras, E 2016. Impact of selected parameters on performance of the Adiabatic Liquid Air Energy Storage system. Journal of Power Technologies 96, 238-244.

18. Marra, F, Træholt, C, Larsen E and Wu Q 2010. Average behavior of batteryelectric vehicles for distributed energy studies. Innovative Smart Grid Technologies Conference Europe (ISGT Europe), IEEE PES, 1-7.

19. http://www.pse.pl/index.php?did=2870. Accessed on: 26.09.2017.

20. Demand for power Innogy Stoen Operator [Zapotrzebowanie Mocy Innogy Stoen Operator]. [26.09.2017]. Available from www.rwestoenoperator.com.pl/zapotrzebowaniemocy.php.

21. Pasaoglu, G, Fiorello, D, Martino, A, Scarcella, G, Alemanno, A, Zubaryeva, A and Thiel, C 2012. Driving and parking patterns of european car drivers-a mobility survey. Luxembourg, European Commission Joint Research Centre.

22. Dallinger, D and Wietschel, M 2012. Grid integration of intermittent renewable energy sources using price-responsive plug-in electric vehicles. Renewable and Sustainable Energy Reviews 16, 3370-3382.

23. Stillwell, D, Pini, C, Cummings, J and Fazil, A 2017. National Travel Survey: England 2016, Department for Transport of United Kingdom.

24. http://www.eafo.eu/europe. Accessed on: 21.09.2017. 
IMPACT OF DEVELOPMENT OF INFRASTRUCTURE FOR CHARGING ELECTRIC 91 VEHICLES ON POWER DEMAND IN THE NATIONAL POWER SYSTEM

\title{
WPŁYW ROZWOJU INFRASTRUKTURY DO ŁADOWANIA POJAZDÓW ELEKTRYCZNYCH NA ZAPOTRZEBOWANIE NA MOC W KRAJOWYM SYSTEMIE ELEKTROENERGETYCZNYM
}

\begin{abstract}
Streszczenie
Przedstawiony powyżej artykuł koncentruje się na rozwoju sektora pojazdów elektrycznych i jego możliwym wpływie na obciążenie systemu elektroenergetycznego w Polsce. Jego celem jest oszacowanie wzrostu zapotrzebowania na moc wynikającego z ładowania samochodów elektrycznych. Przede wszystkim opisano obecne otoczenie prawne, które zapewnia ramy dla ewolucji sektora elektromobilności. Ponadto przedstawiono proces techniczny ładowania pojazdów elektrycznych oraz zaproponowano odpowiednie metody współpracy między samochodami elektrycznymi a systemem elektroenergetycznym. Przeprowadzono analizę ilościową wpływu ładowania pojazdów elektrycznych na zapotrzebowanie mocy w KSE. Podano dane wejściowe i przyjęte założenia. Opisano strukturę modelu obliczeniowego oraz różnice pomiędzy analizowanymi scenariuszami. Model został zaprojektowany do przeprowadzania symulacji dla 15-minutowych interwałów czasowych. Badania przeprowadzono dla trzech różnych udziałów samochodów w pełni elektrycznych (BEV) w całości samochodów elektrycznych (suma BEV i PHEV): $0 \%, 50 \%$ i 100\%. Przedstawiono wyniki uzyskane dla obszaru Krajowego Systemu Elektroenergetycznego i obszaru warszawskiego.
\end{abstract}

Słowa kluczowe e-mobility, samochody elektryczne, ładowanie samochodów elektrycznych, Krajowy System Elektroenergetyczny

Editor received the manuscript: 17.01.2019 